\title{
Resistencia a la rotura y a la abrasión de adoquines de hormigón para pavimentos, en función del peso específico (en seco) y de la velocidad de ultrasonidos
}

\author{
Splitting strength and abrasion resistance of concrete paving \\ blocks as a function of dry bulk specific gravity and ultrasonic \\ pulse velocity
}

\author{
T. HAKTANIR, K. ARI \\ Erciyes University, Turquia \\ Persona de contacto/Corresponding author: thaktanir@erciyes.edu.tr
}

Fecha de recepción: 1-111-04

Fecha de aceptación: 26-XI-04

TURQUIA

\section{RESUMEN}

Los bloques para pavimentos (adoquines) elaborados con hormigón se utilizan habitualmente en numerosos paises. Estos bloques de pavimentación se diseñan de diversas formas, como por ejemplo "Entrelazado" ("Interlocking") o"Flor Italiana" ("Italian Flower"); se fabrican con maquinaria especial y con frecuencia se utiliza hormigón de la más alta calidad, con resistencia a la compresión de alrededor de $50 \mathrm{MPa}$. La razón de utilizar bloques de hormigón en lugar de bloques de piedra natural es básicamente económica. Los equipos de laboratorio necesarios para medir la resistencia a la compresión y a la abrasión -dos de las propiedades más importantes para determinar la calidad de los bloques en estudio-son costosos y los ensayos requieren tiempo y mano de obra considerables. En el presente trabajo se exponen ensayos experimentales que relacionan la resistencia a la tracción indirecta ("split strength") y la resistencia a la abrasión de adoquines de hormigón para pavimentos por su peso especifico en seco (DSGB) y la velocidad de pulsos ultrasónicos (UPV). Como conclusión se dan diversas ecuaciones de regresión que estadísticamente son significativas, utilizando muestras aleatorias procedentes de siete fábricas distintas, con lo que se relaciona la "split strength" con el DSGB y la resistencia a la abrasión con el UPV.

\section{SUMMARY}

Artificial Portland cement concrete paving blocks are widely used in many countries. These paving blocks come in a variety of designs with names such as "Interlocking" and "Italian Flower", and are manufactured with special machinery using rather high quality concrete having a compressive strength of about 50 MPa. Concrete blocks are employed instead of natural cobble stones for essentially economic reasons. The laboratory equipment required to measure paving block splitting strength and abrasion resistance, two of the chief properties to be tested in quality checks, is costly and the tests are time-consuming and labour-intensive. The present paper reports on a detailed experimental study performed to relate the splitting strength and abrasion resistance of concrete paving blocks to "dry bulk specific gravity" (DBSG) and "ultrasonic pulse velocity" (UPV), respectively. Statistically significant regression equations describing the dependence of splitting strength on $D B S G$ and abrasion resistance on UPV were obtained with data from random samples of material provided by seven different manufacturers.

KEYWORDS: concrete paving blocks, mechanical properties, physical properties, tensile splitting strength.

os, propiedades mecánicadoquines de hormigón para pavimen tracción indirecta.

\section{INTRODUCCIÓN}

Los adoquines de rocas naturales, de formas generalmente cúbicas, procedentes del corte de distintas clases de rocas, tales como basaltos y granitos, son unas dos veces más costosos que los bloques de hormigón para pavimentación; por ello, en muchos países estos últimos se utilizan generalmente tanto en vías peatonales como en las destinadas a tráfico rodado. Las distintas formas y colores de los adoquines de hormigón brindan un aspecto agradable a la carretera, constituyendo una ventaja adicional.

\section{INTRODUCTION}

Since natural, usually cube-shaped, cobblestones made of basalt, granite or similar rock are approximately twice as costly as concrete paving blocks, the latter are commonly used both for sidewalks and carriageways in many countries. A second advantage of concrete paving blocks is that they come in assorted shapes and colours, enhancing the appearance of roadways. 
Como es preceptivo para todos los materiales de construcción, un bloque de hormigón necesita ser resistente y duradero. Dada su función en el pavimento, la resistencia a la rotura a compresión debe cumplir las características dadas en PrEN-1338 (1) y TS-2824 (2). La resistencia a la abrasión determinada, ya sea con la técnica de "wide-wheel" o bien a través de la técnica de Böhme, proporciona valores significativos respecto a la durabilidad del material. Esto también se explica en PrEN-1338 (1) y TS-2824 (2).

La resistencia de rotura a compresión y a abrasión de los bloques son dos de las características más importantes que se exigen en los Pliegos de Concesión de Obra para pavimentos de carreteras y de aceras. La medida de la resistencia a compresión requiere disponer de:

1) una prensa para el ensayo a la compresión.

2) accesorio para realizar la tracción indirecta, que se coloca entre los platos de compresión de la prensa.

Este ensayo se describe esquemáticamente en la Figura 2 de la página 12 de la prEN-1338. Para el ensayo de abrasión se necesita una sierra de cortar rocas y el aparato de Böhme. El ensayo de abrasión de Böhme aplicado a una muestra extraída de un bloque de pavimento se describe en la Figura B.1 de la página 45 de prEN-1338 (1). Los ensayos a abrasión, tanto si se realizan con "widewheel" o con Böhme, son pesados, ruidosos y tediosos a causa de la pérdida de tiempo que precisa la extracción de las muestras por aserrado; se necesita refrigeración constante por agua, y se genera una considerable cantidad de polvo. En el presente trabajo se realiza el ensayo Böhme.

El aparato que se conoce como "PUNDIT" mide el tiempo de paso de las ondas de ultrasonido para atravesar un determinado espesor de hormigón y se utiliza para determinar de forma indirecta algunas de sus características físicas, tales como módulo de elasticidad, profundidad de grietas visibles, daño causado por fuego y por heladas y estimación de la resistencia a la compresión (p.ej. BS-1881-203 (3) y ASTM-C597-97 (4)). El precio de un "PUNDIT" no es despreciable, pero resulta mucho menos oneroso que los costos añadidos del corte de la roca con la sierra, y el aparato Böhme. Además, el uso del PUNDIT para la determinación indirecta de propiedades mecánicas básicas del hormigón de cualquier tipo se ha incrementado y se ha hecho frecuente en los últimos años en países de riesgo sísmico, como Grecia y Turquía. La medida de la velocidad de los ultrasonidos a través de cualquier tipo de hormigón mediante un dispositivo "PUNDIT" estándar es sencilla, directa y de corta duración. Por ello, el principal objetivo del presente trabajo ha sido investigar la posibilidad de relacionar el desgaste en una probeta prismática extraída de un bloque de pavimentación (de adoquines), causado por un dispositi-
Like all construction materials, concrete block needs to be both strong and durable. When such block is laid as pavement for pedestrians and motor vehicle traffic, splitting strength is the property primarily regulated in standards such as PrEN-1338 (1) and TS-2824 (2). Abrasion resistance, determined either with a standard wide-wheel abrasion machine or a Böhme apparatus, affords another relevant measure of durability and is likewise addressed in PrEN-1338 (1) and TS-2824 (2).

Splitting strength and abrasion resistance are the two chief parameters defined in the specifications drawn up by authorities tendering sidewalks or carriageways to be paved with these concrete blocks. Splitting tensile testing calls for:

1) a compression machine.

2) an accessory consisting in two rigid bearers placed between the compression platens.

A schematic drawing of this test can be found in standard prEN-1338 (Figure 2, page 12) [1]. The facilities needed for the abrasion test, in turn, include (1) a rock saw and (2) equipment to conduct either the wide wheel or the Böhme test. A diagram of the Böhme test on a paving block specimen is shown in standard PrEN-1338 (Figure B.1, page 45) (1). Both the wide-wheel and Böhme tests are cumbersome, noisy, and time-consuming because they involve cutting cubical samples from paving blocks with a rock saw (cooled and lubricated with a stream of water during the process) and abrading the specimen with the wheel or rotating plate, which generates dust. Abrasion resistance was determined by the Böhme procedure in the present study.

A device commonly known as the "PUNDIT" (for portable ultrasonic non-destructive indicating tester) is used to indirectly determine certain physical properties of concrete-modulus of elasticity, depth of visible cracks, degree of fire or frost damage, and compressive strengthfrom the speed with which ultrasonic pulse waves pass through the concrete sample (e.g., BS-1881-203 (3) and ASTM-C597-97 (4)). Although PUNDITs are certainly not inexpensive, it is still far less costly to acquire one of these devices than a rock saw and a Böhme test apparatus both. Moreover, PUNDIT use has grown increasingly popular in recent years as a method for indirectly determining basic mechanical properties of concrete, especially in earthquake-prone countries such as Greece and Turkey. Measuring the ultrasonic pulse velocity (UPV) through concrete samples with a standard PUNDIT is a simple, straightforward, and speedy operation. Hence, the main objective of this study was to explore the possibility of relating the loss of paving block depth during the Böhme test to ultrasonic pulse velocity through the block. If a statistically significant relationship can be 
vo de abrasión Böhme, con la velocidad de los ultrasonidos a través del bloque. Si se pudiera obtener una relación estadísticamente significativa entre la abrasión y los ultrasonidos (UPV), se posibilitaría deducir, de una forma sencilla, la resistencia a la abrasión y aliviar al personal de laboratorio de los complicados ensayos que exige el ensayo Böhme. Un segundo objetivo de la presente investigación es relacionar la resistencia a la rotura con el peso específico, en seco (DBGS) y con la velocidad de pulso ultrasónico (UPV). En caso de que esto pudiera obtenerse, también se conseguiría, de una forma sencilla, determinar una importante propiedad de los bloques de pavimentación.

\section{RESISTENCIAA LA TRACCIÓN INDIREC- TA DE UN BLOQUE DE PAVIMENTACIÓN}

De acuerdo con PrEN-1338 (1) y TS-2824 (2) la resistencia a tracción indirecta es el criterio que se adopta para los bloques de pavimento de forma preferente al de la resistencia a compresión. El dispositivo de rotura se monta entre los cabezales de carga de la prensa y la probeta del pavimento se coloca entre las dos unidades semicirculares; a continuación se rompe la probeta a la tracción indirecta.

La resistencia de la probeta se calcula con la fórmula dada en la página 14 del PrEN-1338 (1), teniendo en cuenta la relación entre su resistencia a tracción y la carga última de rotura.

\section{RESISTENCIA A LA ABRASIÓN DE UN BLOQUE DE PAVIMENTACIÓN}

De acuerdo con PrEN-1338 (1) y TS-2824 (2), la resistencia a la abrasión de un pavimento puede ser determinada mediante el dispositivo Böhme. Se realiza sobre una probeta extraída al azar del bloque de pavimentación con una sierra adecuada; las dimensiones de dicha probeta serán de $71 \times 71 \times \mathrm{m} \mathrm{mm}$, donde h varía entre 60 y $80 \mathrm{~mm}$; es decir, h representa el espesor del bloque en' estudio. Los detalles del ensayo pueden consultarse en la Parte B. 1 de PrEN - 1138 .

\section{PESO ESPECÍFICO DEL BLOQUE DE PAVIMENTACIÓN}

El peso específico, en seco (DBSG) de un bloque de pavimentación puede determinarse con precisión, al mismo tiempo que la absorción. Para el ensayo se utiliza una cubeta grande llena de agua, un horno de laboratorio y una balanza de Arquímedes de buena sensibilidad. Previamente al ensayo, se mantuvo durante 7 días sumergido en agua un número suficiente de muestras de adoquines established between abrasion loss and UPV, abrasion resistance can be determined simply and conveniently, relieving laboratory staff of the lengthy and burdensome procedures involved in Böhme testing. A second objective was to relate splitting strength to "dry bulk specific gravity" (DBSG) and possibly to the UPV of the paving block. The definition of a meaningful relationship between these two parameters would provide a way to readily determine a second important characteristic of paving blocks.

\section{PAVING BLOCK SPLITTING STRENGTH}

According to both PrEN-1338 (1) and TS-2824 (2), paving block strength is measured more appropriately in terms of splitting tensile than compressive strength. To determine the splitting strength, the sample is placed between two rigid semi-circular bearers which are then mounted between the platens of a compression machine and split in two under indirect tensile stress.

Splitting strength is computed from the formula given in standard PrEN-1338 (1) (page 14), which relates the indirect tensile stress on the cross-sectional area of the specimen to the ultimate load.

\section{PAVING BLOCK ABRASION RESISTANCE}

Codes PrEN-1338 (1) and TS-2824 (2) both specify that the abrasion resistance of a paving block may be determined with a standard Böhme abrasion apparatus. Initially, a prism measuring $71 \times 71 \times \mathrm{hm}$, with $\mathrm{h}$-block thickness-ranging from 60 to $80 \mathrm{~mm}$, is cut from a paving block with a suitable rock saw. A detailed description of the test can be found in Part B.1 of PrEN-1338 (1).

\section{PAVING BLOCK DRY BULK SPECIFIC GRAVITY}

All that is needed to accurately determine the dry bulk specific gravity (DBSG) and absorption capacity of a paving block is a vat filled with water, a standard oven and a sensitive Archimedes balance. Randomly chosen paving blocks were soaked in water for 7 days prior to testing. Since these concrete blocks were more than 28 days old, it was assumed that there would be no 
elegidos al azar. Dado que los bloques estudiados tenían una edad superior a la de 28 días se asume que no hubo una ganancia de resistencia apreciable como consecuencia de la citada permanencia bajo agua durante 7 días. Este ensayo se explica más adelante.

\section{MEDIDA DE LA VELOCIDAD DE ULTRASÓNIDOS A TRAVÉS DEL BLOQUE DE PAVIMENTACIÓN}

La duración del paso de un impulso de ultrasonidos puede medirse fácilmente con un Pundit, que debe cumplir las normas BS-1181-203 (3) y ASTM-C597-97 (4). Se impregnaron ambas caras del bloque con la grasa adecuada para una correcta transmisión de los pulsos ultrasónicos y se midió el tiempo (con una precisión de $0,1 \mu \mathrm{s})$ que el impulso ultrasónico tardaba en atravesar el bloque. Tras intercambiar las sondas receptoras y transmisoras se repitieron las mediciones. De esta manera se obtuvieron valores promedio. En la mayor parte de los ensayos, ambas medidas fueron muy parecidas. El grosor del bloque situado entre las dos sondas, en milímetros, dividido entre la duración (en $\mu$ s) del paso del impulso ultrasónico da como resultado la velocidad de pulso ultrasónico (UPV) en km/s. La Figura 1 representa el ensayo.

\section{TOMA DE MUESTRAS DE LOS BLOQUES Y DESARROLLO DE LOS ENSAYOS}

Siete fabricantes de bloques de pavimentación de hormigón de Turquía facilitaron una gran cantidad de muestras para su estudio; las muestras fueron tomadas al azar. Los investigadores que han realizado el presente trabajo se comprometieron con aquellos fabricantes a no revelar los resultados más que a los responsables de las compañías. Las muestras fueron trasladadas al laboratorio del Departamento de Ingeniería Civil de la Universidad de Erciyes. También se obtuvieron muestras de los áridos empleados appreciable gain in strength due to the possible effect of the 7 day contact with water. The test procedure involved is straightforward and consequently not described here.

\section{MEASUREMENT OF ULTRASONIC PULSE VELOCITY THROUGH A PAVING BLOCK}

The travel time of an ultrasonic pulse can be readily measured with a standard BS-1881-203 (3) and ASTMC597-97 (4) compliant PUNDIT. Standard petroleum jelly was applied to both sides of the block before taking the readings (with a precision of $0.1 \mu \mathrm{s}$ ). Measurements were repeated twice, switching the transmitter and receiver positions; the average of the two readings was recorded as the travel time. The two readings were very similar -and even exactly equal-in most measurements. Dividing the thickness in $\mathrm{mm}$ of the paving block between the transmitter and receiver by the travel time in microseconds ( $\mu \mathrm{s}$ ) gives the UPV in $\mathrm{km} / \mathrm{s}$. See Figure 1 for a photograph of the test set-up.

\section{PAVING BLOCK SAMPLES AND TESTING}

Seven Turkish concrete paving block manufacturers in several different locations across the country were approached and agreed to provide the material needed, subject to the formal commitment to refrain from disclosing the findings and to notify company officials directly of the results. Concrete paving blocks were chosen at random from each plant and shipped to the Erciyes University Civil Engineering Department's materials laboratory. Samples of the aggregate used to manufacture

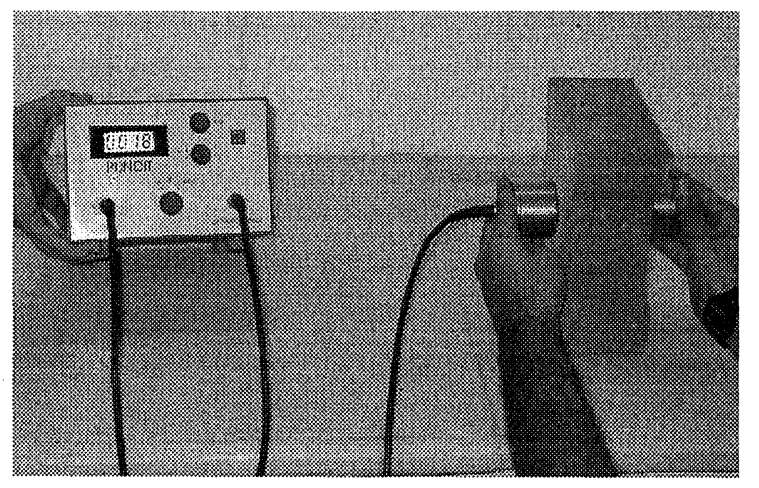

Figura 1.- PUNDIT estándar para la medida de la velocidad de ultrasonidos a través del bloque de pavimentación de horınigón.

Figure 1.- Standard PUNDIT device for measuring ultrasonic pulse velocity through a concrete paving block. 
en la fabricación del hormigón. Se efectuaron tamizados patrones, pesos específicos y medidas de capacidad de absorción. Los ensayos se realizaron por duplicado con áridos de diferentes granulometrías. El tamaño máximo de grano fue de $16 \mathrm{~mm}$ para todos los bloques procedentes de las diferentes fábricas. Se habían empleado áridos naturales y de machaqueo. Varias fábricas utilizaron como material de relleno un mineral impalpable que es un subproducto del proceso de machaqueo de los áridos, que en las cribas de las canteras pasa a través de los tamices más finos. El valor del peso específico en seco de los áridos utilizados en estos bloques osciló entre 2,43 y 2,47 y sus capacidades de absorción, entre $3,7 \%$ y $0,9 \%$, respectivamente.

En primer lugar se midieron, sobre cada una de las ocho muestras de los siete grupos estudiados, los tiempos de paso de los pulsos ultrasónicos, por medio del PUNDIT.

A continuación, se sometió a ensayos de tracción indirecta a ocho muestras del total de los 7 grupos. En forma aleatoria, una mitad de cada uno de los bloques partidos en el ensayo anterior se sometió a los ensayos estándar de densidad y capacidad de absorción.

Las $56(8 \times 7)$ mitades de los bloques se mantuvieron inmersas en agua durante 7 días, exactamente. A continuación, e inmediatamente después de extraídos de las cubetas de inmersión, se drenó el exceso de agua y se eliminó el agua superficial con un paño de algodón. Las muestras, saturada y con la superficie seca, se pesaron al aire y sumergidas en la balanza de Arquímedes, con precisión de $0,1 \mathrm{~g}$. Las muestras se pesaron después de secadas a $110^{\circ} \mathrm{C}$ durante 3 días en un horno de laboratorio con ventilación forzada.

De tres de las otras mitades de los bloques en estudio (tomados al azar) se cortaron probetas de $71 \times 71 \times \mathrm{mm}$, con una sierra para corte de rocas. En total se obtuvieron $3 \times 7=21$ probetas prismáticas En cada muestra se marcaron 9 puntos uniformemente distribuidos, como se puede ver en la Figura B.2 de PrEN-1338 (1). Los puntos fueron cuidadosamente marcados en la superficie opuesta a la cara erosionada de cada una de las muestras y el valor $\mathrm{h}$ de la altura de las probetas se midió con un calibre en cada uno de los 9 puntos marcados, con una precisión de $0,01 \mathrm{~mm}$. A continuación, cada probeta prismática fue sometida a 16 ciclos de 22 revoluciones cada uno, en el equipo de Bohme; se emplearon $20 \mathrm{~g}$ de abrasivo (polvo de corindón) en cada uno de los ciclos. La muestra en estudio se fue rotando $90^{\circ} \mathrm{al}$ final de cada ciclo. Al final de cada uno de los 16 ciclos, en cada uno de los 9 puntos previamente marcados, se midió el espesor. La diferencia de los promedios de espesor entre el comienzo y el final del ensayo es la pérdida por abrasión en PrEN-1338 (1) y TS-2824 (2). the concrete were also obtained and standard sieving and specific gravity and absorption capacity tests were performed twice on each grading. The factories used both natural and crushed aggregate and the maximum grain size found in any was $16 \mathrm{~mm}$. Most plants also used a very fine mineral dust filler, a by-product of the aggregate crushing process that passes through the finest sieve in the aggregate quarry. The dry bulk specific gravities of the aggregate used in these blocks ranged from 2.43 to 2.73 and their respective absorption capacities from $3.7 \%$ to $0.9 \%$.

First, a standard PUNDIT was used to measure the time taken for the ultrasonic pulse to pass through each of the 56 blocks, eight per plant, sampled.

The eight samples per group were subsequently tested for splitting strength. One of the two resulting halves was then randomly chosen to find the standard specific gravity and absorption capacity.

All 56 half-blocks were soaked in water for exactly 7 days. When they were removed from the vat, the excess water was drained off and the surface water was wiped off with a large cotton cloth to weigh the saturated surface-dry samples to a precision of $0.1 \mathrm{~g}$, first in air on an Archimedes balance and then on the same balance, but completely submerged. The samples were weighed a third time after storage in a ventilated oven at a constant temperature of $110^{\circ} \mathrm{C}$ for 3 days.

Prisms measuring 71x71xh $\mathrm{mm}$ were rock-sawed from three half-blocks per group, randomly chosen from the 56 not used in the prior procedure. Nine uniformly distributed points were carefully marked on the abraded surface of each of the $(3 \times 7=21)$ specimens, following the pattern described in PrEN-1338 (Figure B.2) (1) and the depth, $h$, was measured nine times at each point with precision callipers (to $0.01 \mathrm{~mm}$ ). Böhme testing consisted of sixteen 22-rotation abrasion cycles. Twenty grams of special abrasive sand (corundum powder) were poured between the sample and the abrasion track of the rotating disc at the beginning of each cycle and samples were rotated horizontally $90^{\circ}$ between cycles. After the 16 cycles, depth measurements were taken nine times at each of the nine points marked earlier. The difference in the average depths at the beginning and end of the test was recorded as the abrasion loss, as specified in PrEN-1338 (1) and TS-2824 (2). 


\section{PÉRDIDA A LA ABRASIÓN Y RESISTEN- CIAA LA ROTURA EN FUNCIÓN DEL UPVY DBSG DE UN BLOQUE DE PAVIMENTACIÓN}

Dado que un bloque de pavimentación más rígido, con áridos más resistentes, debería mostrar mejor resistencia a la abrasión, se deduce que un bloque con UPV más rápida, también deberá tener una mejor resistencia a la abrasión; es decir, debería haber una relación indirecta entre el UPV y la pérdida por abrasión. La resistencia a la abrasión es casi tan importante como la resistencia mecánica de un pavimento, pues de ella depende el período de vida útil bajo los efectos de desgaste por abrasión producido por peatones o vehículos. De forma similar, la DBSG de un bloque rígido y denso deberá ser elevada, y podría ser una variable independiente potencial para la predicción de la resistencia al desgaste, en un modo no destructivo.

Con un razonamiento similar, se considera que la resistencia a la tracción indirecta podría definirse de manera indirecta como una función de ambos parámetros, DBSG y UPV. A pesar de que muchos laboratorios de hormigón y de materiales de construcción tienen prensas, sería práctico contar con una expresión estadística significante que permita estimar la resistencia a la tracción indirecta. La búsqueda de una expresión matemática, que relacione la pérdida por abrasión y la UPV ha sido el principal objetivo del presente trabajo, ya que el ensayo de tracción indirecta no es demasiado laborioso.

Después de haber obtenido todos los resultados de los ensayos realizados, se probaron numerosos modelos de regresión, tomando como variable dependiente la resistencia a tracción indirecta. Se comprobó que la dependencia entre el valor de la tracción indirecta y el de la UPV es mucho menor que el obtenido con respecto a la DBSG, tanto con respecto a los valores originales como a los valores logarítmicos transformados. La DBSG fue la variable independiente dominante y la inclusión de la UPV como una segunda variable independiente no mejoró el coeficiente de determinación. La ecuación [1] es el modelo de regresión obtenido.

$\log ($ resistencia de tracción indirecta, $\mathrm{MPa})=-1,24+5,40$ $\cdot \log (\mathrm{DBSG})[1]$

En esta expresión, los logaritmos son decimales y el coeficiente de regresión,una vez ajustados los grados de libertad (degree of freedom (D.O.F.)), es $\mathrm{R}^{2}=0,59$. Los valores $t$ de $-1,24$ y 5,40 son $-5,7$ y 8,9 respectivamente, mayores que el valor crítico de $t$ con un D.O.F. de 54 y probabilidad del $99,99 \%$ ( $\mathrm{tcr}=3,46)$, lo que supone que ambos coeficientes de la ecuación [1] son correctos con un $99,99 \%$ de probabilidad. La Figura 2 muestra la representación gráfica de los valores obtenidos, la recta de regresión para la media y los intervalos de confianza del

\section{RELATIONSHIPS BETWEEN PAVING BLOCK ABRASION LOSS, SPLITTING STRENGTH, UPV AND DBSG}

Since stiff paving blocks made with strong aggregate should resist abrasion particularly effectively, it was felt that blocks with fast UPVs should also exhibit high abrasion resistance; in other words, UPV and abrasion loss should be indirectly related. Abrasion resistance provides a measure of durability under the wear of pedestrian traffic or motor vehicle tyres and is therefore almost as important a property of paving blocks as strength. Similarly, DBSG, which should be high in stiff, dense paving blocks, is another potential independent variable that could be used in a non-destructive model for predicting abrasion resistance.

A similar argument provides the rationale for believing that splitting strength can be indirectly defined in terms of both DBSG and UPV. Even though most concrete and materials laboratories are fitted with the type of compression machine needed to measure this parameter, a valid model for splitting strength would still serve a practical purpose. However, inasmuch as the splitting tensile test is a less laborious procedure than the Böhme test, the primary objective of this study was to find a statistically significant relationship between abrasion loss and UPV.

The test results were compiled and numerous regression models tried. The dependent variable in all cases was splitting strength, which was found to depend much more heavily on DBSG than on UPV, regardless of whether the raw or logarithmic values were used. DBSG was the predominant independent variable and the inclusion of $U P V$ as a second independent variable did not improve the determination coefficient. The regression model obtained is given in equation [1] below.

Log (splitting strength, $M P a)=-1.24+5.40 \cdot \log$ (DBSG) [1]

where the logs are common logarithms and the determination coefficient in this regression after adjusting for degree of freedom (D.O.F.) is: $R^{2}=0.59$. The $t$ values for -1.24 and 5.40 are -5.7 and 8.9 , respectively, both of which are greater than the critical $t$ value with a D.O.F. of 54 and a probability of $99.99 \%$ (tcr $=3.46)$; in other words, there is a $99.99 \%$ probability that both coefficients in equation [1] are significant. The data points are plotted on Figure 2, which also shows the regression line for the 
$90 \%$ para la media y para un valor individual de la relación entre la resistencia a la tracción indirecta y la DBSG.

Las tentativas para todos los modelos posibles de regresión para la determinación de la pérdida por desgaste como variable dependiente, revelaron que no existe una relación significativa entre la pérdida por abrasión y la DBSG. Se encontró, sin embargo, una dependencia significativa entre esa pérdida por abrasión y la UPV. La ecuación [2] es el modelo de regresión obtenido.

Pérdida por abrasión $(\mathrm{mm})=14,5-2,53 \cdot \mathrm{UPV}(\mathrm{km} / \mathrm{s})$

El coeficiente de regresión después de ajustado el D.O.F. es $\mathrm{R}^{2}=0,72$.

Los valores de $\mathrm{t}$ 14,5 y -2,53 son 9,2 y -7,3, respectivamente, que son superiores al valor crítico de $t$ con un D.O.F. de 19 y con una probabilidad del 99,99\% (tcr $=3,883)$ lo que significa que los coeficientes de la ecuación [2] son correctos, con un $99,99 \%$ de probabilidad. La Figura 3 muestra la representación gráfíca de los resultadós obtenidos, la rectả de regresión para la media y los intervalos con una confianza del $90 \%$ para la media y para un valor individual de la relación entre la pérdida por desgaste y la UPV.

\section{CONĆLUSIONES}

Se han obtenido ecuaciones de regresión estadísticamente significativas y sus intervalos de confianza, que permiten determinar indirectamente en bloques de pavimento sus resistencias a la tracción indirecta y pérdida por abrasión.

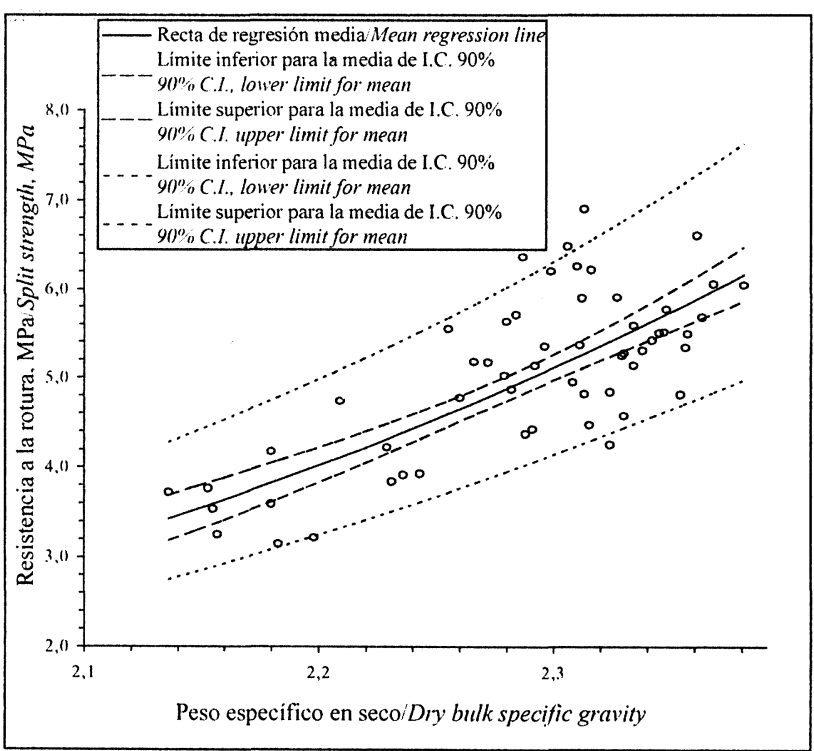

Figura 2.- Resistencia a la rotura vs peso específico en seco en bloques de hormigón para pavimentación.

Figure 2.- Splitting strength versus dry bulk specific gravity in concrete paving blocks. mean as well as the $90 \%$ confidence intervals for the mean and any given value of splitting strength relative to $D B S G$.

No statistically significant relationship could be found between abrasion loss as the dependent variable and $D B S G$ with any of the possible regression models tried. Abrasion loss was, however, found to be depend rather heavily on UPV. The regression model obtained is given as equation [2] below.

$$
\text { Abrasion loss }(\mathrm{mm})=14.5-2.53 \cdot U P V(\mathrm{~km} / \mathrm{s})
$$

The determination coefficient in this regression after adjusting for d.o.f. is: $R^{2}=0.72$.

The $t$ values for 14.5 and -2.53 are 9.2 and -7.3, respectively, both of which are greater than the critical $t$ value with a D.O.F. of 19 and a probability of $99.99 \%$ $($ tcr $=3.883):$ in other words, there is a 99.99\% probability that both mean regression coefficients for equation [2] are significant. The data points are plotted on Figure 3, which also shows the regression line for the mean and the $90 \%$ confidence intervals for the mean and any given value of abrasion loss relative to UPV.

\section{CONCLUSIONS}

Concrete paving block splitting strength and abrasion loss can be indirectly determined from the statistically significant regression equations and confidence intervals defined in this study. Use of the suggested relationships

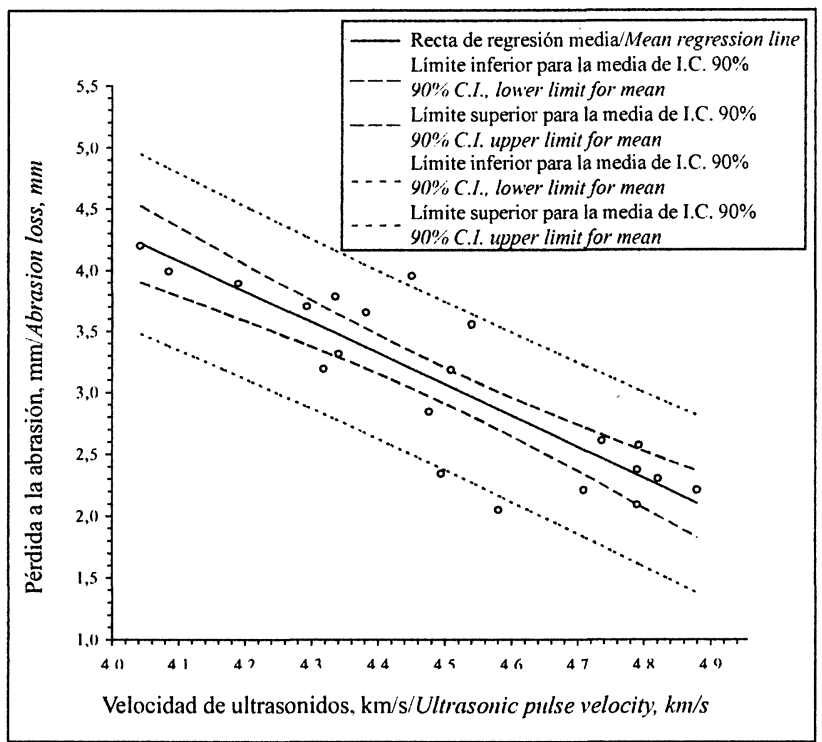

Figura 3.- Pérdida a la abrasión vs velocidad de ultrasonidos en bloques de hormigón para pavimentación.

Figure 3.- Abrasion loss versus ultrasonic pulse velocity in concrete paving blocks. 
El uso de estas ecuaciones librará a los técnicos responsables de largos y laboriosos ensayos para determinar las resistencias a la tracción indirecta y los valores de resistencia a la abrasión en bloques de pavimentos y posibilitará implementar un procedimiento de control en la construcción de capas de rodadura integral práctico y rápido. Las ecuaciones [1] y [2] y las Figuras 2 y 3 proveen de un procedimiento rápido para el control de producto en bloques de pavimento o adoquines. would obviate the need for conducting laborious and timeconsuming splitting strength and abrasion tests, and would provide a practical and speedy procedure for the overall control of road surfacing work. In addition, equations [1] and [2], together with Figures 2 and 3, constitute a practical approach to concrete paving block product control.

\section{BIBLIOGRAFÍA}

(1) CEN, PrEN-1338. Concrete Paving Block. European Committee for Standardisation, Central Secretariat: rue de Stassart 36, B1050 Brussels, Belgium, october 1993.

(2) TSI, TS-2824. Concrete Paving Blocks. Turkish Standards Institute, Necatibey Caddesi, 112 Bakanllklar, Ankara, Turkey, April 1996.

(3) BSI, BS-1881-203. Recommendations for Measurement of Velocity of Ultrasonic Pulses in Concrete (with amendments: $\mathrm{N}^{\circ} .1,28$ february 1991, and $N^{\circ} .2,30$ august 1991). British Standards Institution, 1986.

(4) ASTM, ASTM-C597-97. Standard Test Method for Pulse Velocity through Concrete. American Society for Testing and Materials, june 1998 .

\section{Nota del Consejo de Redacción:}

El Consejo de Redacción de Materiales de Construcción agradece al Prof. T. Vázquez y a L. Fdez. Luco la traducción de la versión española de este artículo.

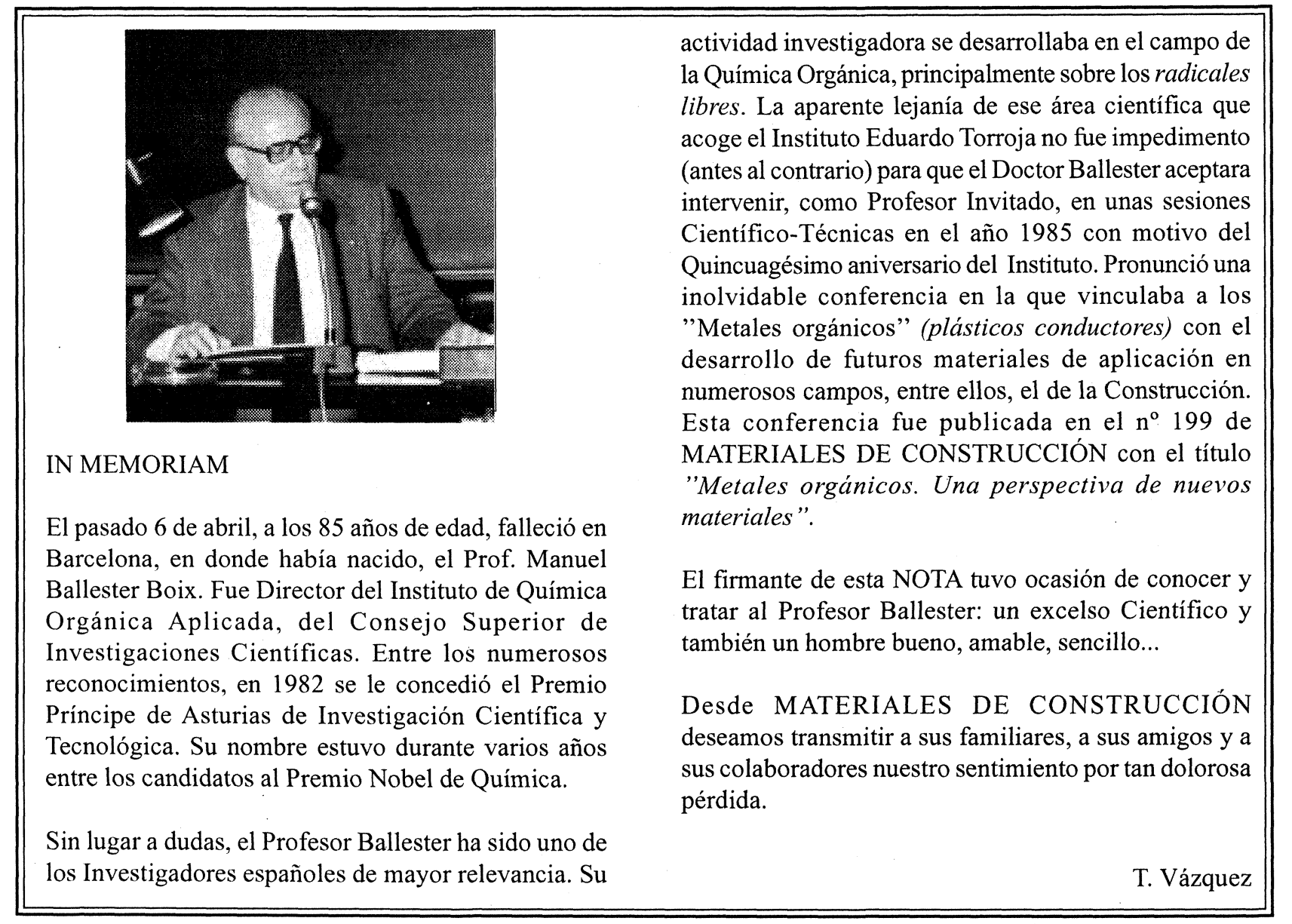

